\title{
Palaeoenvironmental and sequence stratigraphic analyses of the Jurassic Datta Formation, Salt Range, Pakistan
}

\author{
Shahid Iqbal ${ }^{1,2, *}$, Irfan U Jan ${ }^{3}$, M Gulraiz Akhter ${ }^{1}$ and Mehwish Bibi ${ }^{4}$ \\ ${ }^{1}$ Department of Earth Sciences, Quaid-i-Azam University, Islamabad 45320, Pakistan. \\ ${ }^{2}$ Department of Geodynamicss and Sedimentology, University of Vienna, \\ Althanstrasse 14 A-1090 Vienna, Austria. \\ ${ }^{3}$ National Centre of Excellence in Geology, University of Peshawar, Peshawar, Pakistan. \\ ${ }^{4}$ Department of Environmental Sciences, Quaid-i-Azam University, Islamabad, Pakistan. \\ ${ }^{*}$ Corresponding author.e-mail: siqbal_geol@yahoo.com
}

The Lower Jurassic Datta Formation, western Salt Range, Pakistan, comprises three facies associations: (1) channel belt facies association (CBFA), (2) channel margin, and overbank facies association (CMOFA), and (3) lagoonal facies association (LFA). A cyclic fining-upward trend in the succession is represented by basal quartzose conglomerate/pebbly sandstone, through coarse to fine quartzose sandstone to siltstone and shales/claystone, which contains some carbonate accumulation. Two prominent depositional sequences are recognized in the Datta Formation with the lower high and upper low magnitude cycles. The Datta Formation thus represents a thick sedimentary succession and in the study area, i.e., western Salt Range, mainly channel belt, flood plain and/or delta top facies are exposed. The palaeocurrent analysis shows that the source area with acidic plutonic rocks laid to S-SE in the Indian shield, aravalies or older sedimentary rocks of the Indus Basin (i.e., Khewra, Tobra and Warchha formations). A tentative stratigraphic correlation of the Datta Formation with the lower Jurassic Lathi Formation, India invites further work in parts of India, which will elaborate the extent of the Datta Formation in the Greater Indian peninsula and develop palaeogeographic setting for this Lower Jurassic deltaic rock unit.

\section{Introduction}

The Jurassic Datta Formation in the western Salt Range, Pakistan (figure 1a, b and c) represents a thick siliciclastic rock unit with some minor carbonate accumulation. The succession holds appreciable hydrocarbon, fire clay and silica sand deposits and thus has proved economically very significant. However, despite being economically important, the strata has received very limited research attention in the study area, i.e., the western Salt Range. Elsewhere, in the Salt Range and Trans-Indus ranges (figure 1b), the lithofacies, sand body geometry, and depositional palaeoenvironments have been investigated for this unit (i.e., Ashraf et al. 1976; Rafique et al. 1976;
Fatmi et al. 1990; Mujtaba and Memon 1990; Chaudhry et al. 1994; Obaid et al. 2005; Abbasi et al. 2012).

The type locality of the Datta Formation lies in the Surghar Range, where the reported thickness is $212 \mathrm{~m}$ (Fatmi 1974, 1977). The formation is widely distributed in the Salt Range, and Trans-Indus ranges, parts of Kohat Plateau, Kala Chitta, and Hazara areas. In the Salt Range (table 1), it is welldeveloped in the western part, i.e., Nammal Gorge section, showing a maximum recorded thickness, i.e., $150 \mathrm{~m}$, with eastward decrease in thickness (figure $1 \mathrm{~b}$ and c). In the study area, i.e., Kaowaali and Kasanwala sections, the thickness recorded is 121.5 and $83.7 \mathrm{~m}$, respectively (figures $1 \mathrm{c}$ and 2).

Keywords. Lower Jurassic; Datta Formation; Salt Range; Indian shield; Indus Basin. 


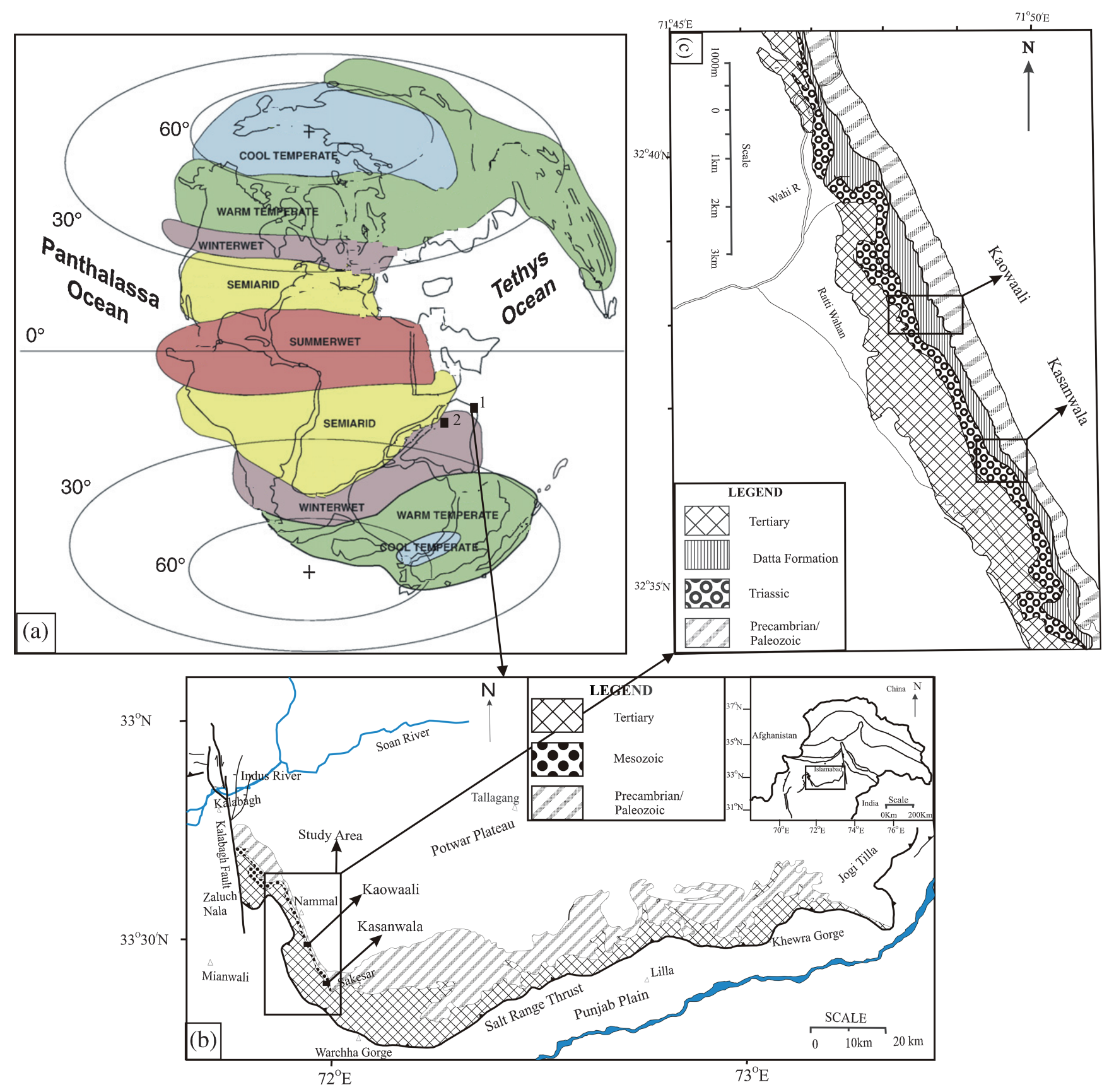

Figure 1. Current and palaeogeographic location of the Salt Range, Pakistan. (a) Early Jurassic palaeogeographic location of the study area, showing, 1. Salt Range, 2. Jaisalmer (India). (b) Location of Salt Range. The map (c) inset shows locations where the study was conducted (modified after Rees et al. 2000; Gee 1980, 1989).

The formation has a disconformable lower contact with the Triassic Kingriali Formation (figure 3a) and the upper contact with the Palaeocene Hangu Formation (figure $3 \mathrm{~b}$ ).

The Datta Formation represents first Jurassic sedimentation following the Late Triassic unconformity (Shah 1977, 2009; Abbasi et al. 2012). The present study aims to understand the depositional setting and sequence stratigraphic architecture of the Datta Formation in the western Salt Range, based on investigation in the field and petrographic studies in the laboratory (figures 3-6). This study interprets the depositional palaeoenvironments of different lithofacies in the Datta Formation, establishes facies association for the formation, and explains its depositional sequence stratigraphic architecture. It further makes an effort to present a tentative palaeodepositional model for the formation based on interrelationship of the various lithofacies, facies association, and sequence stratigraphic architecture. This study may thus help in establishing the position of the Datta Formation as an important horizon for regional and global correlating, following the Late Triassic disconformity. 
Table 1. Lithostratigraphic units of the Kohat-Potwar Plateau. The Datta Formation is highlighted in bold (modified after Iqbal et al. 2014).

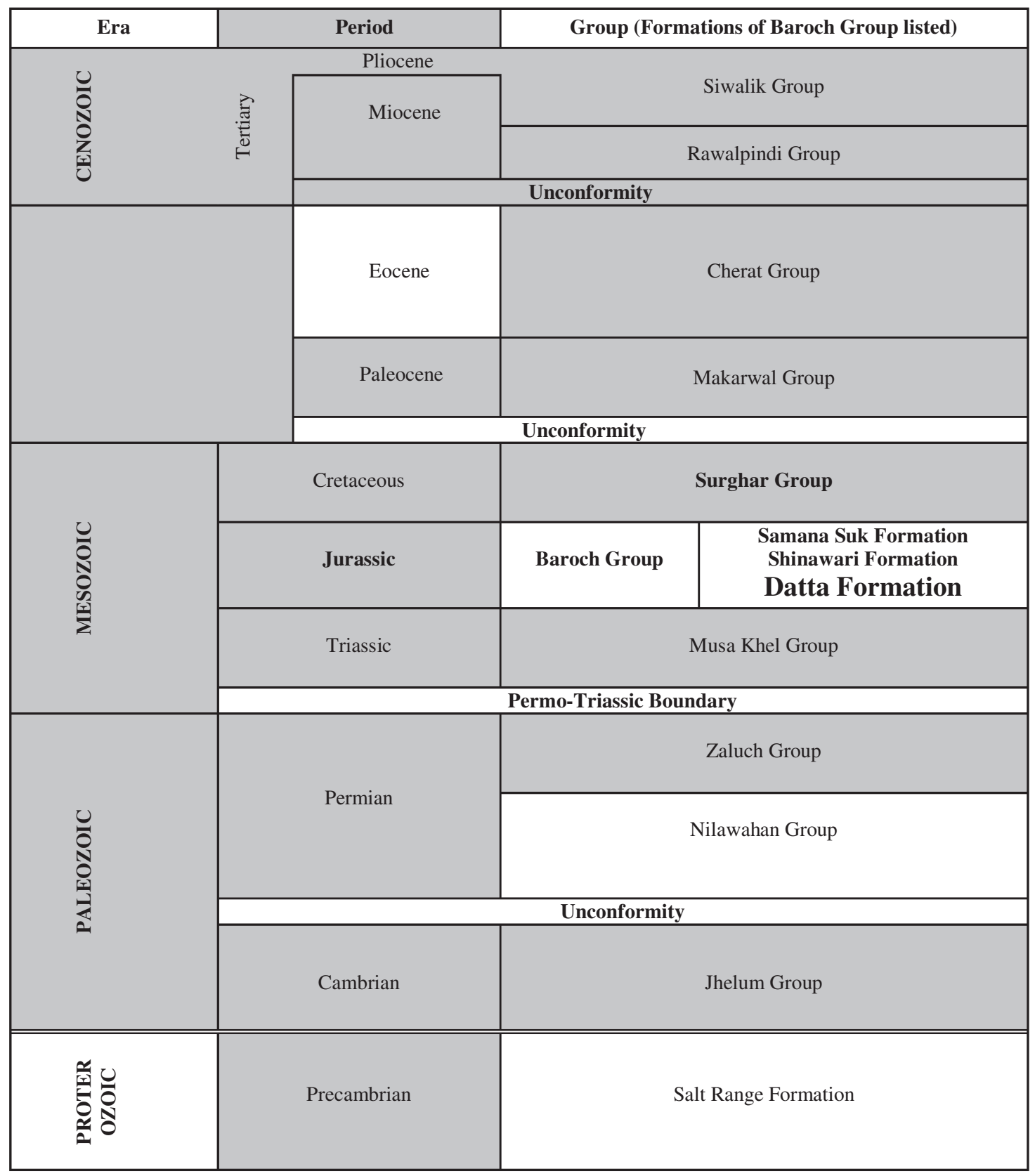

\section{Palaeogeography and tectonics}

The Salt Range occupied a location at the northwestern extremity of the Indian Plate, i.e., $\sim 25^{\circ} \mathrm{S}$, along the Tethyan margin during Early Jurassic (Rees et al. 1999, 2002; Damborenea 2002; Arias 2007; figure 1a). The Pangaea break up in the Jurassic and subsequent rifting of the Indian Plate from Africa and Arabia resulted in many conspicuous topographic features and in the Potwar Plateau many subsurface normal faults were produced, which are interpreted based on seismic data and geological sections (e.g., Kadri 1995; Kazmi and Jan 1997). Additionally, the low density evaporites of the Infracambrian Salt Range
Formation uplifted the northwestern margin of the Indian Plate, a phenomenon resembling the Jurassic salt mobilization in the Infracambrian to Cambrian Ara Formation of the Huqf Group on the Arabian Plate (Murris 1980). This uplift resulted in the westnorthwestward depression in the area and subsequent development of the fluvial system, which in Pakistan resulted in the deposition of the Datta Formation.

Likewise, in many Indian basins, deep erosion, faulting, tilting of strata mark a post-Early Norian hiatus. This represents a complete change of depositional setting and a sedimentation break between the underlying Late Triassic and Late Pliensbachian sediments within the Gondwana basins of India 


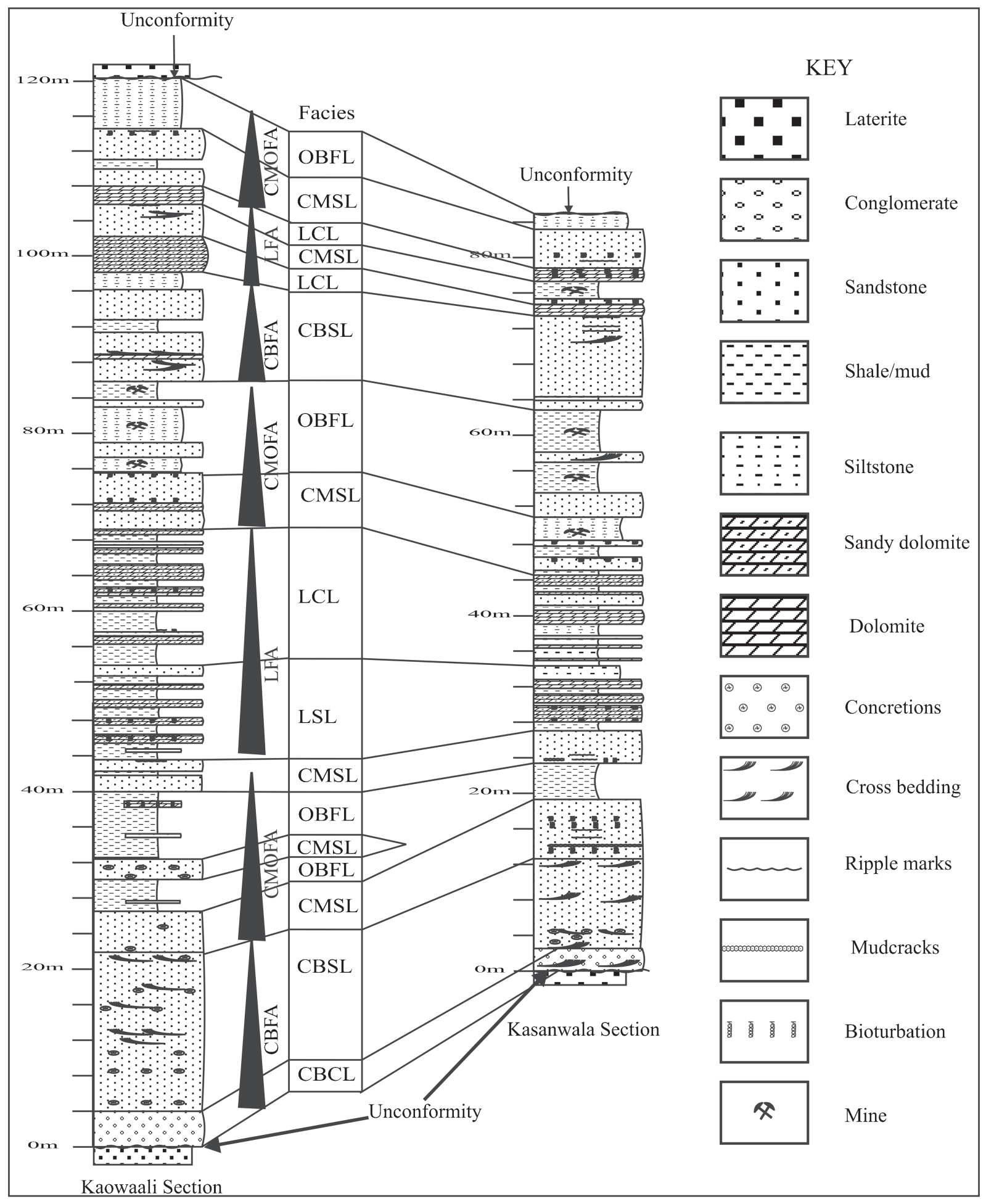

Figure 2. Stratigraphic sections measured for the Datta Formation at the studied locations. CBCL=Channel Belt Conglomerate Lithofacies, CBSL=Channel Belt Sandstone Lithofacies, CMSL=Channel Margin Sandstone Lithofacies, OBFL $=$ Overbank/Floodplain Lithofacies, LSL=Lagoonal Shale Lithofacies, LCL=Lagoonal Carbonates Lithofacies, $\mathrm{CBFA}=$ Channel Belt Facies Association, $\mathrm{CMOFA}=$ Channel Margin and Overbank Facies Association and LFA=Lagoonal Facies Association.

(Mukhopadhyay et al. 2010). The ongoing Himalayan orogeny uplifted the Precambrian-Cenozoic strata, along the Salt Range Thrust, over the Molasse-type sediments of the Punjab Plain (Baker et al. 1988; Kazmi and Jan 1997).

\section{Material and methods}

The Lower Jurassic Datta Formation was studied in the western Salt Range (figure $1 b$ and c). Sections of the Datta Formation were studied at the 

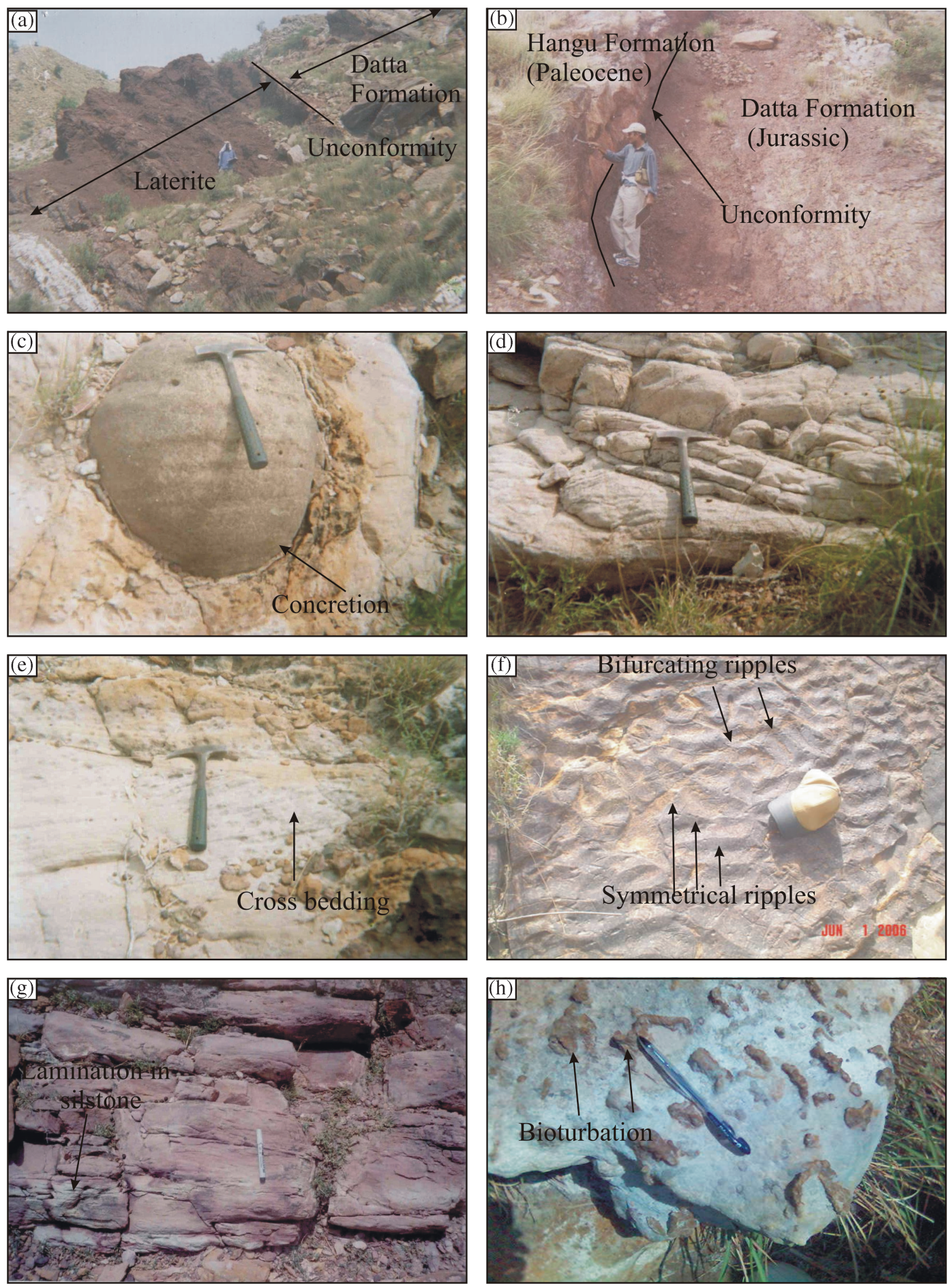

Figure 3. Characteristic lithofacies present in the Datta Formation of the Salt Range, (a) lower contact of the Datta Formation at Kasanwala section, (b) upper contact of the Datta Formation at Kaowaali section, (c) concretions in the CBSL, (d) quartz-rich sandstone of the CBSL, (e) cross-bedding in the CBSL, (f) ripple marks in CMSL, (g) oxidised sandstone in OBFL, and (h) bioturbation in OBFL.

Kasanwala Nala and Kaowaali section (figures 1b, c and 2). The two sections are easily accessible and the formation has excellent continuous exposures in both the sections (figure 2). Sedimentological analyses of the Datta Formation were carried out in the two sections; field observations (mesoscopic) and petrographic studies were performed. The lithofacies (figure 2) were traced for vertical and lateral changes, i.e., variations in the bedding behaviour and bedding types (e.g., pinching out and thickening, coarsening and/or fining up). Marker horizons such as erosional surfaces, oxidized zones, palaeosoles, rippled and cross-bedded horizons and beds with plant remains were identified. Photographs of all 
the important structures and features were taken (figure 3). Samples for petrography and grain size analysis from the formation were collected (43 from Kasanwala Nala and 59 from Kaowaali section). Olympus BX41 microscopic with DP12 camera was used for petrographic studies to determine the grain composition, size and shape parameters of the lithofacies in the Datta Formation (figure 4). The lithologic logs were prepared and positions of samples were plotted. 20 samples were selected for XRD analysis from the two sections (figure 7). X-Ray Diffractometer (JEOL) 1987 JDX-60PX was used for XRD analysis. The petrographic analyses combined with the field observations produced a refined interpretation of the lithofacies and facies associations. A schematic palaeodepositional model was suggested for the formation in the study area and various palaeodepositional subenvironments for the lithofacies were marked.

\section{Sedimentary facies analysis}

Six distinctive lithofacies are recognized in the Datta Formation in two sections (figure 2), making up various proportions. These are discussed as follows.

\subsection{Channel belt conglomerate lithofacies (CBCL)}

Description. The lithofacies comprises clastsupported conglomerate (Boggs 2006, 2009), dark to yellowish brown (i.e., at the Kaowaali section) and light to dark grey (at the Kasanwala section). The maximum thickness attained is $4 \mathrm{~m}$ (figure 2). The lithofacies is characterized by dominance of granule to pebble sized clasts $(1.25-5 \mathrm{~cm})$ and finer sediments also exist, showing good sorting. Rock fragments constitute $50-75 \%$ of the lithofacies. Pebble size quartz, chert, quartzite constitute more than $90 \%$ of the clasts while granitic rock fragments also occur (figure 4a). Occasional angular, poorly sorted dolomite and sandstone clasts are also present but these constitute less than $10 \%$ of the clasts but these (especially the angular, poorly sorted dolomite clasts) make significant proportion $(20-30 \%)$ of the clasts in the lowermost bed at the contact with the underlying Kingriali Formation. The proportionally insignificant matrix consists of fine to coarse quartz rich sand and iron rich material (figure 4a). The effects of oxidation are prominent in the lithofacies at Kaowaali section only. Individual beds are 1-1.2 m thick and can be traced over 1000-1500 m, while lateral pinching/ thinning is observed. Erosive basal bedding plans are commonly observed. Cross and graded bedding are the other important sedimentary structures, which are present at places. Trough cross stratification is identified and the cross bed sets display fining-upward trends.

Most of the conglomerates are classified as quartzose conglomerates with ultrastable quartz, quartzite, and chert being the dominant rock fragments (Pettijohn et al. 1973, Folk 1974; Pettijohn 1975; Boggs 2009). However, the conglomerates in the lowermost part of the lithofacies that contain 20-30\% angular and poorly sorted clasts of dolomite are classified as petromictic conglomerates (Boggs 2009). The clasts are mostly sub- to well-rounded, well- to very well-sorted and smooth margins are common (figure 4a). Long, linear contacts are common and concave-convex and sutured contacts though present, are rare. Fracturing is a common diagenitic phenomenon and haematite is common cementing material, which postdates fracturing (figure $4 \mathrm{a}$ ). At places, second phase finegrained quartz is introduced into the pore spaces between the grains. The lithofacies has an erosive basal plain and topographic variation of the palaeodepositional surface is observed.

Interpretation. The basal bed with unsorted and angular dolomite fragments indicates that the clasts were derived from the underlying Triassic Kingriali Formation, marking facies dislocation (Iqbal et al. 2014), which occurred due to a prominent relative sea-level fall (Reynolds 1994). The presence of petromict conglomerate containing highly soluble/unstable clasts of dolomite imply rapid erosion of elevated highlands (Smith et al. 2006; Boggs 2009). On the other hand, such unstable carbonate clasts may also represent accumulation under very cold condition where glacial activity provides the eroded clasts (Boggs 2009). In the present case, the thick laterite at the base of the Datta Formation and the dominance of ultrastable clasts in the quartzose conglomerates of the lithofacies favour clasts formation in humid palaeoclimate and inhibit the possibilities of occurrence of cold glacial palaeoclimate.

The individual beds of the lithofacies display fining upward trend, a feature generally not observed in sheet flood (braided stream) conglomerates, though the braided stream conglomerates generally display a fining upward trend that is observed in the present lithofacies (Boggs 2006, 2009; Smith et al. 2009; Lunt et al. 2013). On the other hand, the stream flow conglomerates (meander channel belt conglomerates) display well developed fining upward trends and commonly exhibit well developed cross beddings (Boggs 2009). Both these features are observed in the lithofacies. Further the presence of dominant finer material (i.e., siltstones and shale) in the overlying lithofacies indicates 

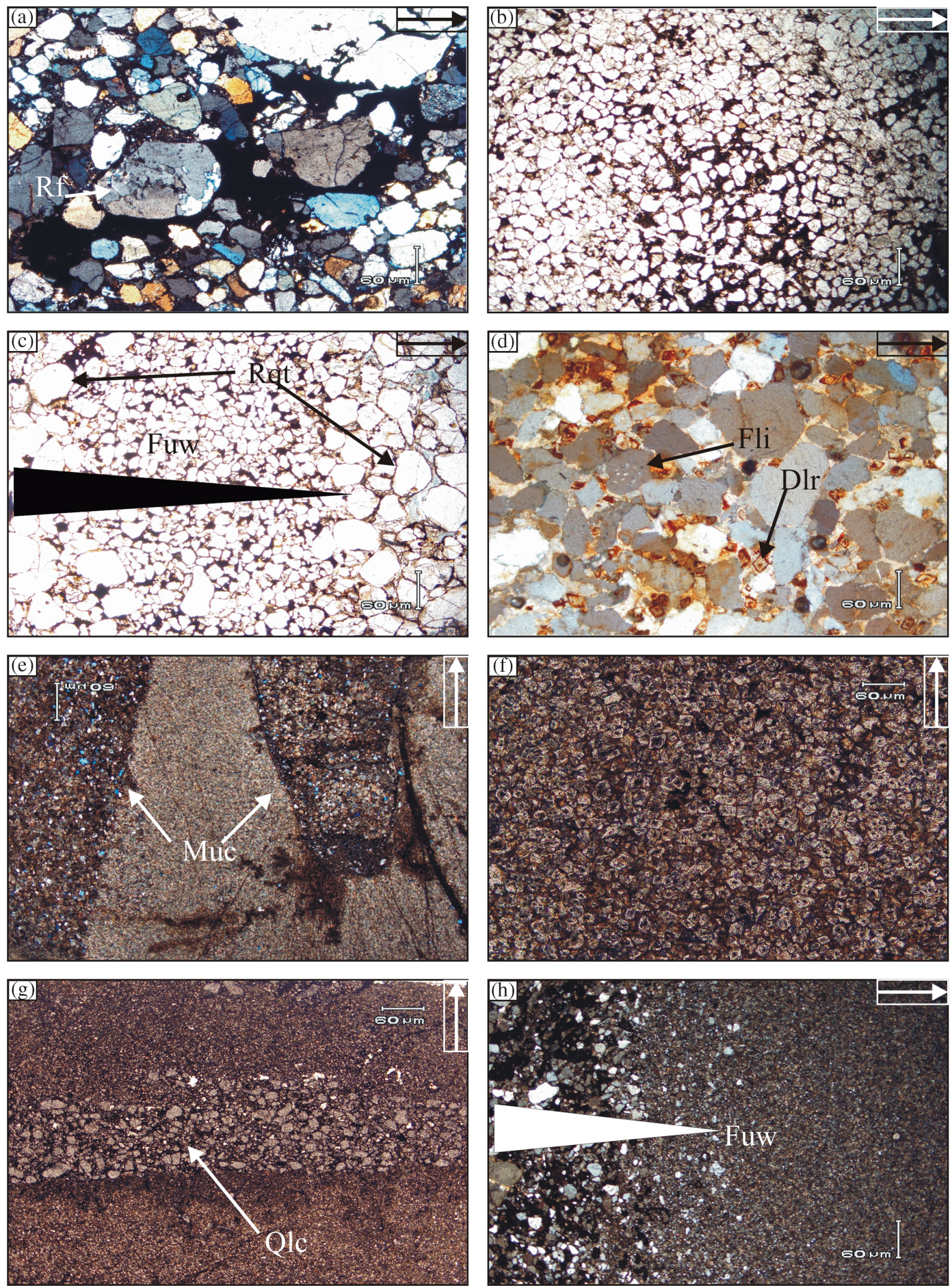

Figure 4. Representative photomicrographs of the lithofacies in the Datta Formation. The arrow in each case indicates the bed top. (a) Quart-rich conglomerate, (b) quartz-rich sandstone of CMSL cemented by iron oxide, (c) fining upward cycle in the quartz-rich sandstone of CBSL, (d) quartz-rich sandstone having dolomite rhombs in CBSL, (e) mudcracks in dolomite of LSL, (f) pure dolo-mudstone of LCL, (g) sharp base quartz-rich layer (pulse) in dolomite of LCL, and (h) fining upward clastics merging into carbonates in LSL. Rf: rock fragments, Rqt: rounded quartz, Fuw: fining upward, Fli: fluid inclusions, Dlr: dolomite rhombs, Muc: mudcracks, Qlc: quartz layer in carbonates.

that the lithofacies formed in a meandering stream. However, the upward decrease in the cross bedding in this lithofacies supports the deposition in a braided stream (Nichols 2000). In general, it is difficult to assign this lithofacies to a braided or meandering river; however, as braiding can be a part of a large meander too, the most likely depositional setting is the point bar. 


\subsection{Channel belt sandstone lithofacies (CBSL)}

Description. The lithofacies comprises of medium to thick and very thick bedded (Boggs 2006) quartz arenites (figures $3 \mathrm{c}-\mathrm{e}$ and $4 \mathrm{~d}$ ), showing variable thickness (figure 2). The lithofacies occurs at several stratigraphic levels and shows a wide range of shades, i.e., light grey to dark grey, maroon, red and dark brown. The beds can be traced for few meters and lateral pinching/lenticular bedding (figure 3e) and lateral accretion is observed (Cadle and Cairncross 1993), especially in the lower part of the lithofacies (first occurrence of the lithofacies). Further erosive bedding plans/reactivation surfaces are observed in the beds and trough cross bedding and planar bedding plans (Boggs 2009) are more common in the upper part of the lithofacies. The sandstone is medium to coarse to very coarsegrained and some pebbly bases are also observed. An overall fining upward trend is observed in the lithofacies and the individual beds also display a fining upward trend. More than $90 \%$ of the quartz is moderate- to well-sorted and mostly rounded monocrystalline (e.g., figure 4b-d). Spherical concretions (figure $3 \mathrm{c}$ ), ranging in diameter from 2 to $45 \mathrm{~cm}$ are common in the lower part of the lithofacies, which impart a red/maroon colouration to the lithofacies. These concretions are truncating the bedding plans and the bedding plans are not curved at their margins. Planar and trough cross bedding is observed in the lithofacies of which the trough cross bedding predominates. Large scale trough cross bedding (figure 3e) is common in the lithofacies, while planar cross bedding is also observable in the upper part.

The palaeocurrent direction is $\mathrm{S}-\mathrm{SE}$ to $\mathrm{N}-\mathrm{NW}$ (figure 5). Occasionally some ripples are found at or near the top of this lithofacies, which include bifurcating and symmetrical ripples (figure 3f) in a ripple terrain (Reineck and Singh 1975; Boggs 2009). The absence of mudcraks, bioturbation and presence of very rare ripple marks differentiate this lithofacies from the overlying fine- to very finegrained sandstones of the channel margin. Some scattered coal patches/carbonaceous material is also observed at the top of this lithofacies.

Interpretation. The large scale planar and trough cross beds are produced by the migration of megacurrent ripples (e.g., Reineck and Singh 1975). They indicate deeper depths of channels, i.e., more than $4.5 \mathrm{~m}$ (Freedman and Sanders 1978). Symmetrical ripples indicate relatively less sedimentation but pronounced reworking (Reineck and Singh 1975), conditions generally common in the upper flow regime during flood. Widespread ripple marks are generally present in the upper part of the bar sequences, natural levees, crevasse splays, and other flood plain deposits but are lacking here. The spherical concretions represent a diagenetic feature as the lamination/bedding planes of the sandstones are not inclined in the zones of concretions but are rather straight and undisturbed (Blatt 1982). An overall fining upward trend is present both in channel bar and point bar deposits, so is also cross bedding (Ferguson and Werritty 1983). In the present case, fining upward trend occurs at individual bed level, a feature generally not observed in channel bar deposits and common in point bars (Boggs 2009). Further trough cross beds that mostly characterize the lower part of the point bar sequence are observed (Massari 1983; Cadle and Cairncross 1993) and planar cross beds occur in the upper part of the lithofacies. However, the convolute bedding and slumping commonly observed in the upper part of channel bars are absent. On the other hand, the lenticular channelized bedding and lateral accretion observed in the lithofacies, is generally
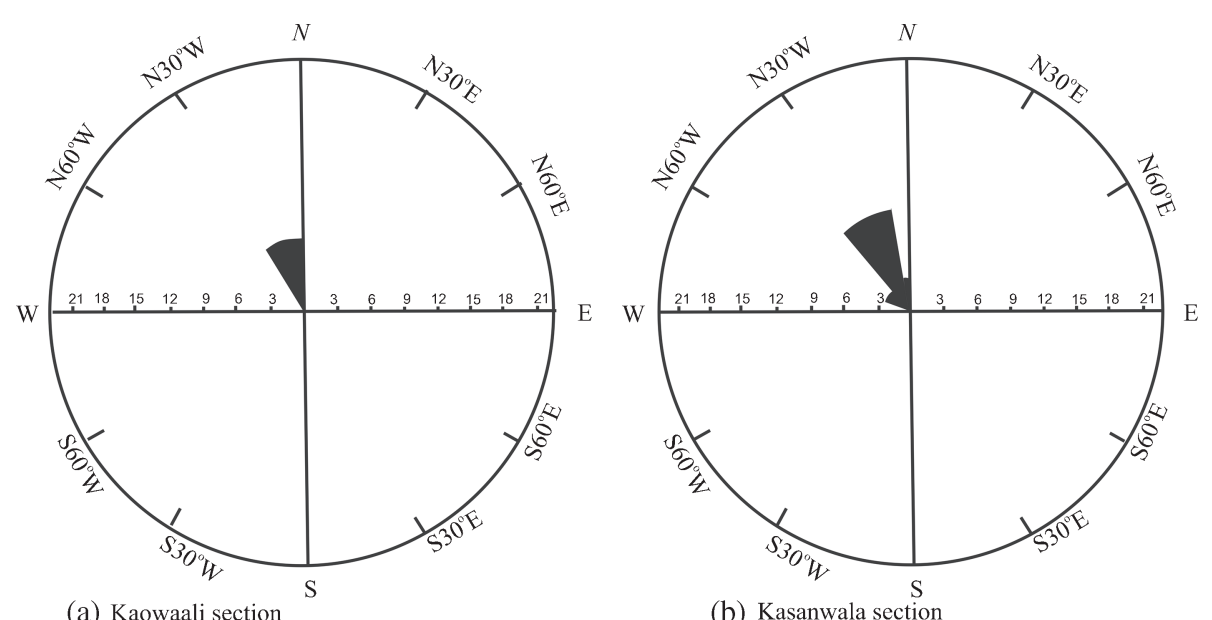

(a) Kaowaali section

(b) Kasanwala section

Figure 5. Palaeocurrent analysis of the Datta Formation in (a) Kaowaali and (b) Kasanwala sections. The readings on the $\mathrm{E}-\mathrm{W}$ line indicate the number of data points. 


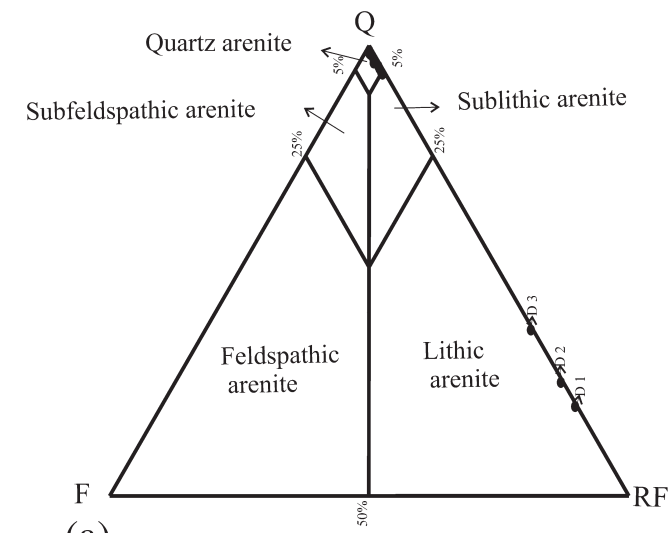

(a)

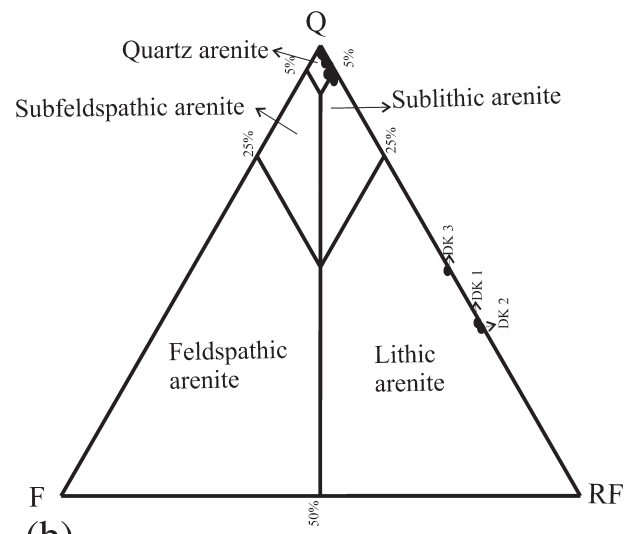

(b)

Figure 6. The QFR diagram of the Datta Formation and interpretation of the provenance. See figure 2 for key of samples; (a) Kaowaali section and (b) Kasanwala section (c.f. Pettijohn et al. 1973; Pettijohn 1974).

common in point bar deposits (Miall 1985; Willis 1989).

Based on the above discussion and relationship with the underlying CBCL, the lithofacies represents point bar deposition top of CBCL (Tucker 1986, 1992).

\subsection{Channel margin sandstone lithofacies (CMSL)}

Description. The lithofacies predominantly consists of thin-to-medium and occasionally thickbedded sandstone. Individual beds can be traced in outcrop for few meters. Planar and wavy bedding planes and lateral pinching and lenticular bedding are observed. The sandstone is fine- to vey fine-grained and pink, yellowish to dark brown (figure 3g). Fining upward cycles are represented and the sandstones grade first into siltstones and then to clay/shales. The associated shale is white, light grey, orange and occasionally dark brown to black in colour and shows lamination. Sedimentary structures include ripple marks, mudcracks, occasional bioturbation features, internal contortion, and raindrop imprints. Symmetrical, asymmetrical, and bifurcating ripples are observed (figure $3 \mathrm{f}$ ). The symmetrical ripples have a wavelength of $10-15 \mathrm{~cm}$ and height of $3-5 \mathrm{~cm}$. Absence of dominant large scale cross bedding, presence of ripple marks, mudcracks, bioturbation, raindrop imprints, and other similar features differentiate this lithofacies from the underlying CBSL lithofacies. Cross bedding is observed but the cross beds sets are thin as compared to those of the underlying CBSL lithofacies. A similar S-SE to N-NW palaeocurrent flow is indicated with some minor variations.

Petrographic and XRD studies suggest that the sandstones are composed of sub-angular to rounded and moderately-well sorted to very well-sorted quartz. More than $90 \%$ of the quartz are monocrystalline and have unit extinction. Iron oxide is the common cementing material and most of the quartz grains float in iron oxide (haematite) and point contacts between the grains are the most (figure $4 \mathrm{~b}$ ). The grain margins are mostly smooth but corroded margins may also be observed. The sandstone is a quartz arenite (figure $6 \mathrm{a}$ and $\mathrm{b}$ ). The quartz rich composition is also confirmed by the XRD analysis (figure 7).

Interpretation. The absence of large scale planar cross beds indicate the lacking of migrating megacurrent ripples (e.g., Reineck and Singh 1975; Boggs $2006,2009)$. Presence of symmetrical ripples indicates relatively less sedimentation and strong reworking (Reineck and Singh 1975; Cadle and Cairncross 1993). Such conditions are common in the upper flow regime during flooding in the upper part of the channel margin environments, natural levees, crevasse splays, and other flood plain deposits (Miall 1985; Willis 1989; Boggs 2009). The presence of mudcracks, bioturbation, and raindrop imprints suggest subaerial conditions (Remin et al. 2014). These inferences strengthen the deposition of this lithofacies in the channel margin near floodplain environments. The presence of associated channel belt facies of CBCL and CBSL, suggest a channel margin environment for this lithofacies with some effects of channel at the proximal extreme and floodplain environment at the distal extreme.

\subsection{Overbank/floodplain lithofacies (OBFL)}

Description. The lithofacies comprises of shale and siltstone with thin interbeds $(3-10 \mathrm{~cm})$ of sandstone (McKee and Weir 1953; Ingram 1954). This lithofacies is common in the middle and upper parts of the studied sections (figure 2), and is frequently underlain by channel margin sandstone 

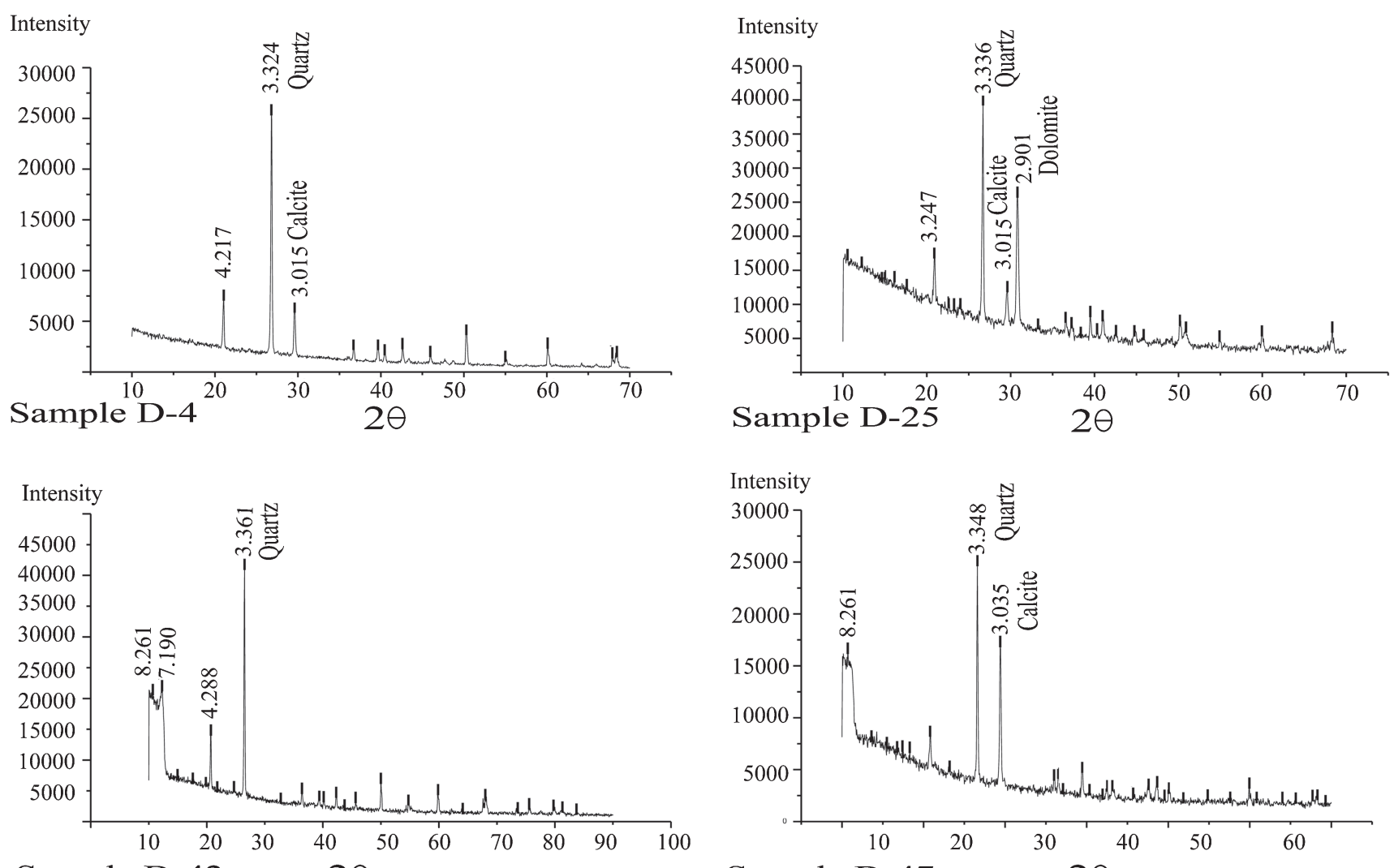

Sample D-42

\section{Sample D-47 $2 \ominus$}
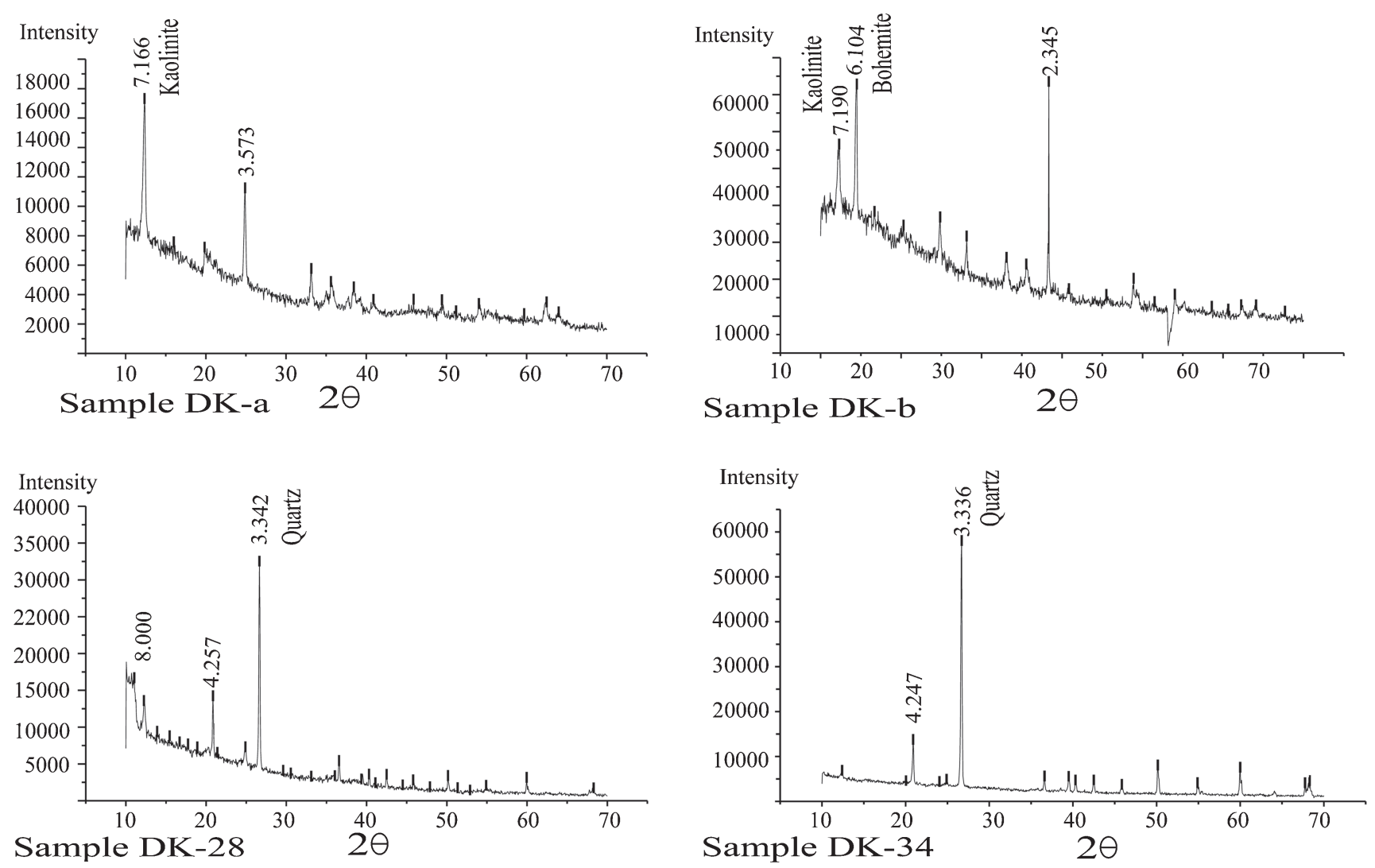

Figure 7. XRD analysis of the selected samples from the Datta Formation. Labelled peaks in each sample represent the dominant minerals in the samples. 
lithofacies (CMSL) and only occasionally by channel belt lithofacies (CBSL). The white, light grey, pink and reddish brown shales are internally laminated.

Petrographic and XRD analyses indicated the presence of quartz only (figure 7). The siltstones and sandstones are varicoloured and thin- to thickbedded. Oxidation effects are commonly observed in the siltstones and sandstones. The sedimentary structures observed are small scale cross-bedding (up to $10 \mathrm{~cm}$ ), ripple marks, wavy bedding planes, and features interpreted as mudcracks. Climbing ripples and bioturbation features are also present. Plant remains are observed at the base of the sandstone beds. Oxidized surfaces with disintegration, dissolution, and features like mudcracks are common, showing palaeosols. The siltstones and associated shales contain deposits of fire clay (figure 2).

Interpretation. The fine-grained siliciclastic materials indicate deposition in low energy settings (Reineck and Singh 1975; Nichols 2000). The presence of fire clay indicates that parts of the lithofacies experienced weathering and soil forming processes (Tucker 1988, 1992). This also indicates a site of deposition that was not completely submerged but had undergone periodic exposure. Such conditions are usually observed in the fluvial channel margin and flood plain settings (Freedman and Sanders 1978) and also in the delta plain. The distinction between them is usually undertaken on the basis of the association of subenvironments that characterize the delta and the relationship to other facies in the stratigraphic section (Nichols 2000). The lithofacies commonly overlies the channel margin sandstone lithofacies (CMSL) and is occasionally associated with the channel belt sandstone lithofacies CBSL (figure 2). The presence of climbing ripples, plant remains, and other similar features suggest deposition in overbank/floodplain environments. The presence of rare fining upward trends in the associated CMSL supports the deltaic environment; the distributary channels (Nichols 2000). The lithofacies is overlain by lagoonal shale lithofacies, which also indicates the close relationship to deltaic/lagoonal subenvironments.

\subsection{Lagoonal shale lithofacies (LSL)}

Description. The lithofacies consists of predominant shale and subsidiary sandstone and siltstones. Minor, thin-bedded carbonates, $0.1-0.3 \mathrm{~m}$ thick, are also found associated with the shale (figure 2). The shale is carbonaceous, black and dark brown in colour in contrast to the white, pink shale/clays of the OBFL but shows a similar quartz-rich composition. A $1-2.5 \mathrm{~m}$ thick coaly shale bed is observed in the middle part of this lithofacies. The associated sandstone/siltstones beds are light to dark grey and ash colour. Sharp basal bedding planes are observed and are fine- to very fine-grained.

Vertical and inclined burrows (figure $3 \mathrm{~h}$ ) are observed and mudcracks are also common. The associated sandstones/siltstones contain symmetrical ripples. The sandstones/siltstones show coarsening upward trend. Few planar cross beds of less than $10 \mathrm{~cm}$ in thickness are also observed at places.

The associated thin bedded carbonates are yellowish orange to light brown in colour and petrographic and XRD analyses show that most of the carbonates contain quartz grains. These can be termed as dolo-mudstones and arenaceous dolomudstones (Dunham 1962). Sharp based, gradually fining upward quartz pulses (figure 4g) are observed at many places and at places siliciclastic deposition gradually fining upward and finally merging into carbonate deposition is also observed (figure 4h).

Interpretation. The lithofacies is devoid of any fossils and thus hard to assign to an environment confidently. However, the associated lithologies, i.e., the interbedded sandstones and siltstonescontain bioturbation, vertical, and inclined burrows. All the associated subenvironments of lagoons, including mudflats contain abundant bioturbation features, fauna, and organic material (Tucker 1992). The presence of coal supports deposition in a relative sea-level rise and flooding conditions, where poorly drained channels and flood plain are potential sites of such deposits (Emery and Myers 1996). The silty and muddy sediments can form on the lagoon bottom or in the low energy channels (Reineck and Singh 1975). A small scale fining upward trend may be present in the distributary channel. At the same time, the interdistributary bay contains thin sand/silt beds formed due to influx of sediment from the fluvial/delta top and symmetrical ripples due to wave action, but has a coarsening upward trend (Nichols 2000). Thus features of interdistributary bay are indicated in the present case.

Carbonate deposition favours settings of rather minor terrigenous input (Nichols 2000). However, the presence of thin layers of quartz in the carbonate (figure $4 \mathrm{~g}$ ) suggests some periodic influx of the siliciclastic grains. The fining upward of the siliclastics and finally merging into carbonate deposition (figure 4h) indicates facies mixing (Mount 1984), while fine grained siliclastics (shale) indicate deposition in less agitated environment, a condition generally observed in the interdistributary 
bay (Nichols 2000). Source mixing (Mount 1984) may be a more appropriate reason for this change from shales to carbonates. The context of this lithofacies, i.e., association with OBFL (i.e., overbank/floodplain lithofacies) suggests a site having similar conditions as the delta plain or delta front environment. The shallow water environment inferred for the carbonates suggests a location not far from the land in an area where clastic input resulted in facies mixing in areas such as abandoned delta lobe or one of the interdistributary bay/lagoonal environments during a relative sea-level rise.

\subsection{Lagoonal carbonate lithofacies (LCL)}

Description. The lithofacies consists predominantly of carbonates with minor shale and very rare sandstone. The carbonates, mainly represented by yellowish brown dolomites, are commonly found associated with the shale and vary in thickness from $0.1-1.5 \mathrm{~m}$. The petrographic and XRD studies show that most of the dolomites are pure (i.e., dolostones), while some contain significant amounts of quartz and impure carbonates (i.e., arenaceous dolo-mudstones; figures $4 \mathrm{e}-\mathrm{h}$ and 7 ). The associated shale/clay is similar to that of LSL, but very minor sand/silt is associated in the present case. The sedimentary structures present in the sandstones are vertical to inclined burrows and some features interpreted as mudcracks also occur. The associated sandstones contain symmetrical ripples and show a fining upward trend.

Interpretation. Carbonate deposition, in general, favours settings of minor terrigenous input (Nichols 2000). However, the presence of shale and few quartz-rich sand beds (figure $4 \mathrm{~g}$ ) suggest some periodic siliciclastic influx. Thus facies mixing (Mount 1984) like the one discussed earlier is reported here. Most recently uplift and erosion of the underlying Late Triassic Kingriali Formation (carbonates) and carbonate clasts incorporation into the overlying beds of the Datta Formation along the Triassic--Jurassic boundary is reported in the area (Iqbal et al. 2014). A similar source mixing is also reported in the marginal marine deposits of the Mesozoic Gabriani Formation of Greece (Price 1977). The fining upward of the siliclastics indicates a waning siliclastic supply and calm deposition in less agitated carbonate environment, a condition generally observed in the interdistributary bay/lagoonal settings (figure 4h, Nichols 2000; Catuneanu 2006). The occurrence of this lithofacies in association with LSL suggests a site reflecting similar conditions as the delta plain or delta front environment. The shallow water environment inferred for the carbonates suggests calm condition than that of LSL. Such an area could be delta plain where an abandoned delta lobe existed or on the interdistributary bay/lagoonal settings.

The bioturbation indicates a shallow, less agitated water environment of deposition for the lithofacies, while the occurrence of mudcracks represents subaerial exposure.

Seasonal/periodic sea-level fluctuation and/or sediment source mixing of the delta lobes were responsible for the deposition of the minor siliciclastics.

\section{Facies association}

The distinctive lithofacies recognized are grouped into three associations. These facies associations belong to the delta channels, delta plain, and delta top subenvironments of the complex deltaic system. All the tree facies associations are discussed in the following lines.

\subsection{Channel belt facies association (CBFA)}

The channel belt facies association (CBFA) comprises of channel belt conglomerate lithofacies (CBCL) and channel belt sandstone lithofacies (CBSL). This association primarily represents the basal part of the formation in both sections (figure 2) and is partly repeated at several levels up section (i.e., CBSL lithofacies). A general E-W increase in thickness is observed for this association. The association is typically recognized by the basal conglomerates of CBCL overlain by thick, cross-bedded sandstones of CBSL that contain prominent concretions (figure 3c). Mostly planar beds with planar bedding plans are observed, however erosional bedding plans are also observed especially at the base of the conglomerates. Cross bed sets are common in the sandstones. The association of CBCL and CBSL lithofacies suggests a bar deposit in the channel/distributary channel palaeoenvironment (Tucker 1992).

\subsection{Channel margin and overbank facies association (CMOFA)}

The channel margin and overbank facies association (CMOFA) comprises of the channel margin lithofacies (CMSL) and overbank/floodplain lithofacies (OBFL). This association overlies CBFA in the lower part of the formation and is overlain by the lagoonal facies association (LFA). In the middle and upper parts of the formation, it overlies LFA and is overlain by CBFA. The sandstones here are different to those of CBFA and contain mudcracks, 
bioturbation features, and ripple marks which are not common in CBFA, while concretions which are common feature of CBFA are not present here. Similarly, trough cross bedding is lacking and planar cross bedding is observed at very few places. The sandstones are fine-grained as compared to those of CBFA.

\subsection{Lagoonal facies association (LFA)}

The lagoonal facies association (LFA) comprises of the lagoonal shale lithofacies (LSL) and lagoonal carbonate lithofacies (LCL). The shale in contrast to the oxidized shale of the CMOFA is mostly black, dark brown, and ash colour. Similarly, the sandstone/siltstones are thin-bedded, fine-grained and cross bedding is minor while mostly symmetrical ripples are observed. Bioturbation activity is also an important feature of the lithofacies.

\section{Discussion}

\subsection{Palaeoenvironments and sequence stratigraphy of the Datta Formation}

The Datta Formation represents an interval of massive siliciclastic deposition subsequent to Triassic dolomite deposition (e.g., Shah 1977). The presence of residual laterite zone indicates intense chemical weathering under humid tropicalnear tropical conditions (Tucker 1992) and represents a candidate type 1 sequence boundary of higher hierarchical order (Posamentier et al. 1988; Posamentier and Vail 1988; Van Wagoner et al. 1990; Wood 1990; Wood et al. 1991; Westcott 1993; Emery and Myers 1996). The presence of boehmite, kaolinite, and other likewise minerals in the laterite zone (figure 7) indicate a warm, humid, tropical to near tropical climate at the onset of Datta deposition that prevailed throughout the formation (Abbasi et al. 2012).

\subsubsection{Lower lowstand systems tract}

The conglomerates (figures 2 and 8) of CBCL represent an abrupt juxtaposition of the fluvial/ continental basal channel belt deposits on top of the underlying thick marine dolomites of the Triassic Kingriali Formation (figure 8), representing a facies dislocation in incised valley after the incised valleys are gradually filled by the fluvial channels during the slow relative sea-level rise stage of the lowstand system tract (Marzo et al. 1988; Van Wagoner et al. 1990). The presence of dolomitic fragments in the basal conglomerate bed indicate reworking and incorporation of the underlying/surrounding nearby Kingriali Formation, a process in which a stream dissipates its energy by erosion of the channel banks, resulting in the widening of the stream channel and increasing width of the incised valley more than that of the fluvial channel itself. The width:thickness ratio is around 1:1000 that matches with the ratio for valley fills of Reynolds (1994) and is in contrast to his 1:100 ratio for channels.

The overlying (figure 2) channel belt sandstone lithofacies (CBSL) is characterized by mediumto coarse-grained trough cross-bedded sandstones with pebbly bases that is overlain by planar crossbedded medium- to coarse-grained sandstone. This fining upward succession indicates a renewed alluvial aggradation, associated with initial slow relative sea-level rise, following a base level fall (figure $8)$. The relative sea-level rise rates are slightly higher compared to that of the basal conglomerates of the incised valley and thus deposit multistoreymultilateral sand bodies; however, these still represent the lower valley/channel fills (Emery and Myers 1996). These sands represent deposition in the relatively accelerated sea-level rise, during the lowstand systems tract (LST). Thin coal patches at the top of several beds within this unit indicate top of the episodic sea-level rise (Van Wagoner et al. 1990).

The overlying (figures 2 and 8) channel margin sandstones are fine- to medium-grained sheet sands having associated siltstone and shale/clays. These sediments indicate increasing relative sea-level rise and associated increase in the accommodation space resulting in decrease of the overall stream gradient and hence decrease in the fluvial capability to transport coarse sand and gravels. This resulted in an increase in the sinuosity of the channels, formation of meander channels and belts, and more effective subdivisions into channel and flood-plain components (Emery and Myers 1996). These fine-grained sands and associated silt and clays thus represent respective channel and channel margin sedimentation during accelerated relative sea-level rise and are candidates for marking top of the LST. The top of this unit probably marks a transgressive surface and hence, the top of the lowstand systems tract. Thus, the Datta Formation from its base (type 1 sequence boundary) up to this candidate transgressive surface represents lowstand systems tract (LST) deposits, which are 27-m thick in the north-northwest (Kaowaali section) and thins out to $19 \mathrm{~m}$ in the east-southeast (at Kasanwala section).

\subsubsection{Lower transgressive systems tract}

The overbank/floodplain shale dominated unit overlies the thick LST succession. The lower boundary is interpreted as a transgressive surface (TS) and 


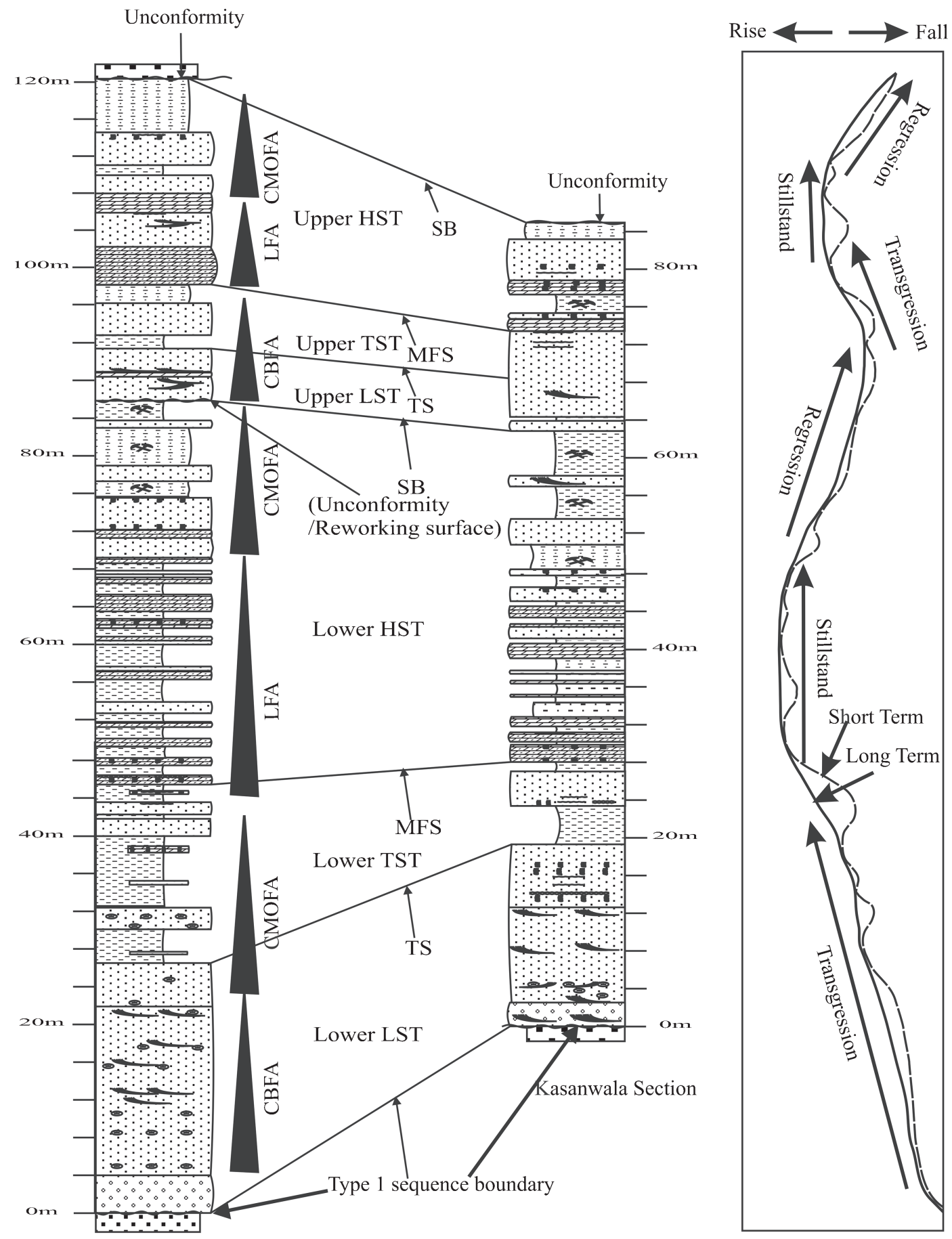

Kaowaali Section

Figure 8. Distribution of different systems tracts and sequence boundaries. LST: Lowstand Systems Tract, TS: Transgressive surface, TST: Transgressive Systems Tract, MFS: Maximum Flooding Surface, HST: Highstand Systems Tract and SB: Sequence Boundary. A composite sea-level curve is suggested for both the sections in the right side of the figure. Please see figure 2 for key (modified after Haq et al. 1987).

the unit indicates a balance between sediment supply and relative sea-level rise. The dominance of shale/clays may indicate a reduction in the fluvial gradient as increase in the crevasse and similar channel margin deposits (figure 8) to promote an attempt to maintain grade with rising base level (Ryseth 1989; Tornqvist 1993). This unit thus represents deposition in the basal part of transgressive systems tract (TST), following the transgressive surface.

The lagoonal shales/clays and the associated lagoonal carbonates (figure 8) indicate deposition in an accelerating relative sea-level rise. The succession indicates cyclic deepening and the presence of 
possible flooding surfaces at the top of each cycle is indicated by the occurrence of shale. A tentative maximum flooding surface may be placed at the top of thickest shale unit which is $1-2.5 \mathrm{~m}$ and contains coal (Ryer 1981; Atkinson 1986; figure 8).

\subsubsection{Lower highstand systems tract}

Following the maximum flooding surface, deposition of the lagoonal carbonates and shale/clay continues and $4 \mathrm{~m}$ (Kasanwala section) to $10 \mathrm{~m}$ (Kaowaali section) of the same unit is deposited above the MFS. The uniform thickness of the interbedded shale/clays and carbonates (i.e., dolomites) indicate deposition in a relatively still stand of sea-level. This sequence is representing lower part of the highstand systems tract (HST), deposited following the MFS (Richards 1994). However, these facies show very close resemblance to the late TST deposits and differentiation between the two is difficult. The lower part of HST is overlain by fine-grained sandstones of the channel margin lithofacies marking a fall in the relative sea-level and the onset of channel margin/ floodplain conditions. These in turn are overlain by the repetition of the overbank/floodplain lithofacies shale/clays marking a further drop in relative sea-level in the proximal locations during the upper part of the HST. However, it is noteworthy that the relative sea-level drop associated with later HST resulted in drop in the base level. The fluvial channel switching resulted in the establishment of fluvial channels and the overbank/floodplain suffered exposure (Shanley et al. 1993) and were subjected to humid, tropical-near tropical weathering. This is indicated by the presence of thick fire clay deposits in the upper, regressive part of the HST. The upper surface of the HST is marked by $10-30 \mathrm{~cm}$ pebbly sandstone bed with erosive base marking a sequence boundary and probably the onset of the next LST (Gowland and Riding 1991).

\subsubsection{Upper lowstand systems tract}

Overlying the HST is the sequence boundary and the next LST. The LST is characterized by the deposition of medium- to coarse-grained channel belt sandstones, while the basal channel conglomerates are absent. This LST appears to be associated with a minor relative sea-level fall than the one at the base of the formation. On the other hand, the possibility of the delta lobe switching, channel migration, and lateral accretion cannot be discarded as reasons for the onset of new fluvial conditions and deposition of channel belt sandstones on top of the HST deposits (Shanley et al. 1993).
Thus a candidate sequence boundary is marked below this LST rather than a proven one. The upper surface of this LST is marked in Kasanwala section by rippled, bioturbated fine-grained sandstone, whereas in Kaowaali section siltstone and shale/clay are present (figure 8). These mark the onset of new trasgressive surface (TS) associated with new relative sea-level rise and/or delta lobes/channel switching. This is marked as second transgressive surface and boundary of the second LST.

\subsubsection{Upper transgressive and highstand system tracts}

The LST is again overlain by carbonates and shale/ clays (figure 2) similar to those described earlier and are considered as deposits of the next but smaller TST. A tentative flooding surface is marked on top of the last dolomite beds in both the sections as black shale is not observed here. This may be the maximum flooding surface (MFS) and thus the boundary of the TST. This TST is finally overlain by the $12-14 \mathrm{~m}$ thick channel margin and overbank/floodplain facies, similar to those discussed in the earlier HST. This represents the second repetition of the HST.

The lateral channel variation, delta channel fluctuation may have played a dominant role in the distribution of various lithofacies in this upper part of the formation. The top of this HST is a major sequence boundary (Type 1 sequence boundary). This boundary marks the upper contact of the Datta Formation with the Paleocene Hangu Formation (figure 3b), a major disconformity along which the upper Jurassic and entire Cretaceous succession is missing (Shah 1977).

\subsection{Palaeoclimate and sea-level changes}

The Jurassic marks the time of significant breakup of Pangaea (Chandler et al. 1992; Moore et al. 1992; Valdes and Sellwood 1992; Chandler 1994; Fawcett et al. 1994; Valdes 1994). The associated northward drift of the Indian Plate during the Mesozoic into a warm-humid tropical to subtropical climatic zone at approximately $25^{\circ}-30^{\circ} \mathrm{S}$ of the equator in the Early Jurassic, resulted in a substantial increase in humidity and rainfall compared to the hot and arid conditions in most of the Triassic period (Parrish et al. 1982; Ziegler 1982; Hallam 1984; Scotese 1994). This interplay between temperature and rainfall remained the main controlling factor of the Early Jurassic palaeoenvironments and sea level fluctuations (Hallam 1981, 1997, 2001). The study area, located at the northwestern margin of the Indian Plate evidenced likewise conditions. The warm and 
humid conditions are represented at the unconformity below the formation characterized by residual laterite formation and presence of boehmite, kaolinite, and other similar minerals which are products of such conditions (Dera et al. 2009). The lower channel belt conglomerate facies and the adjoining channel belt sandstone lithofacies (figure 9a) are representative of deposition in warm, humid conditions and in a lowstand of relative sea-level. This indicates the most proximal deposition of the Datta Formation in an incised valley and associated meander channel belt (figure 9a and b). Minor relative sea-level fluctuations are indicated by the presence of coal patches at the top of many sandstone beds in this unit. These rocks are overlain by fine sandstones, siltstones and clays/shale indicative of warm tropical deltaic deposition in a rising stage of relative sea-level. These upsections merge into the lagoonal shale/clays and associated carbonates with features of warm, lagoonal, lake and near shore marine environments in a relative sea level rise conditions (maximum relative sea-level rise in the formation). This sequence is overlain by a number of palaeosols, laterites, and fire clay horizons, all indicative of warm and humid palaeoclimate under conditions of falling relative sealevel. Plant remains, bioturbation activity indicate moist conditions and water availability under warm conditions. The formation from its base up to this unit most probably represents a 3rd order depositional sequence that starts with the LST, merges into the TST, following a transgressive surface and HST deposition following the MFS (figure 8).

A distinct shift in the facies from overbank/ floodplain deposits to more channel belt facies and disappearance of carbonates is observed on top of this unit. This indicates a second but minor episode of relative sea-level fall and onset of channel belt environment. Further, upsection in both the studied locations is overlain by similar carbonates and shale/clays and fine sandstone as discussed earlier. These features in the upper part of the formation indicate an interplay between sediment supply, and channel/delta lobs migration associated with very minor fluctuation in relative sea-level in proximal locations of the delta top/fluvial subenvironments (figure 9). This unit probably represents another 3rd order depositional cycle containing LST followed by a TST and HST (figure 8).

It is interpreted that the Jurassic time, as suggested by Hallam (1984) and in reconstructed rainfall maps for the Pliensbachian (Parrish et al. 1982), suggest that the climate was sufficiently uniform to establish a relatively uniform warm and humid palaeoclimate. Investigations of clay mineralogy (Dera et al. 2009) and palaeosols of the formation indicate a warm, humid climate (Graff-Petersen and Bondam 1963; Arndorff 1993).

\subsection{Palaeo-depositional model and correlation}

The present study suggests a tentative palaeodepositional model for the Datta Formation in the study area based on the lithofacies distribution and palaeo-depositional environments interpretation (figure 9a and b). Based on the proportion of the various lithofacies/environmental indicators in the two sections, it is suggested that the Kasanwala section located in the S-SE of the study area represents more landward deposits whereas the Kaowaali section (located in the N-NW) represents a more basin ward part of the study area. An overall increase in thickness trend from S-SE (Kasanwala) to N-NW (Kaowaali) is observed (figure 2). A detail of the distribution of fluvio-continental lithofacies can be observed in figure 9(a). A fining upward vertical succession is elaborated that starts from coarse-grained Channel Belt Conglomerate Lithofacies (CBCL) overlain by Channel Belt Sandstone Lithofacies (CBSL) and Channel Margin Sandstone Lithofacies (CMSL). The first two lithofacies constitute the Channel Belt Facies Association (CBFA). This is overlain by Channel Margin and Over Bank Facies Association (CMOFA). This basal succession in both sections is interpreted as point bar deposits (figure 9a).

In the N-NW part of the study area, the presence of Lagoonal Shale Lithofacies (LSL) and Lagoonal Carbonate Lithofacies (LCL) is indicated (figure $9 \mathrm{~b}$ ). These two comprise the Lagoonal Facies Association (figure 9b) and presence of more basinal conditions with marine influence.

The palaeo-depositional model in general suggests that either the thick deposition occurred in N-NW part of the study area or the pre-Palaeocene erosion was more severe in the S-SE part. However, since the individual facies can be traced in both the sections and there is an overall decrease in the thickness of the individual lithofacies (figure 2), it is suggested that the first possibility appears to be a stronger reason for facies control of the Datta Formation in the area.

The Datta Formation is characterized by the occurrence of quartz-rich sands, fire clay and ferruginous horizons and is host to significant hydrocarbons in the Kohat-Potwar Plateau of north Pakistan (e.g., Kazmi and Abbas 2001). The formation provides excellent sections in the western Salt Range, Trans Indus ranges, and KohatPotwar-Hazara area for local and global correlation. Coarse-grained sandstones, conglomeratic at places and mixed with fine siliciclastics and some carbonates occur in the Kachh and Jaisalmer area of India (Gaetani and Garzanti 1991; Verma et al. 2012). The Datta Formation displays a good lithological and environmental correlation with the economically significant Lathi Formation of the 


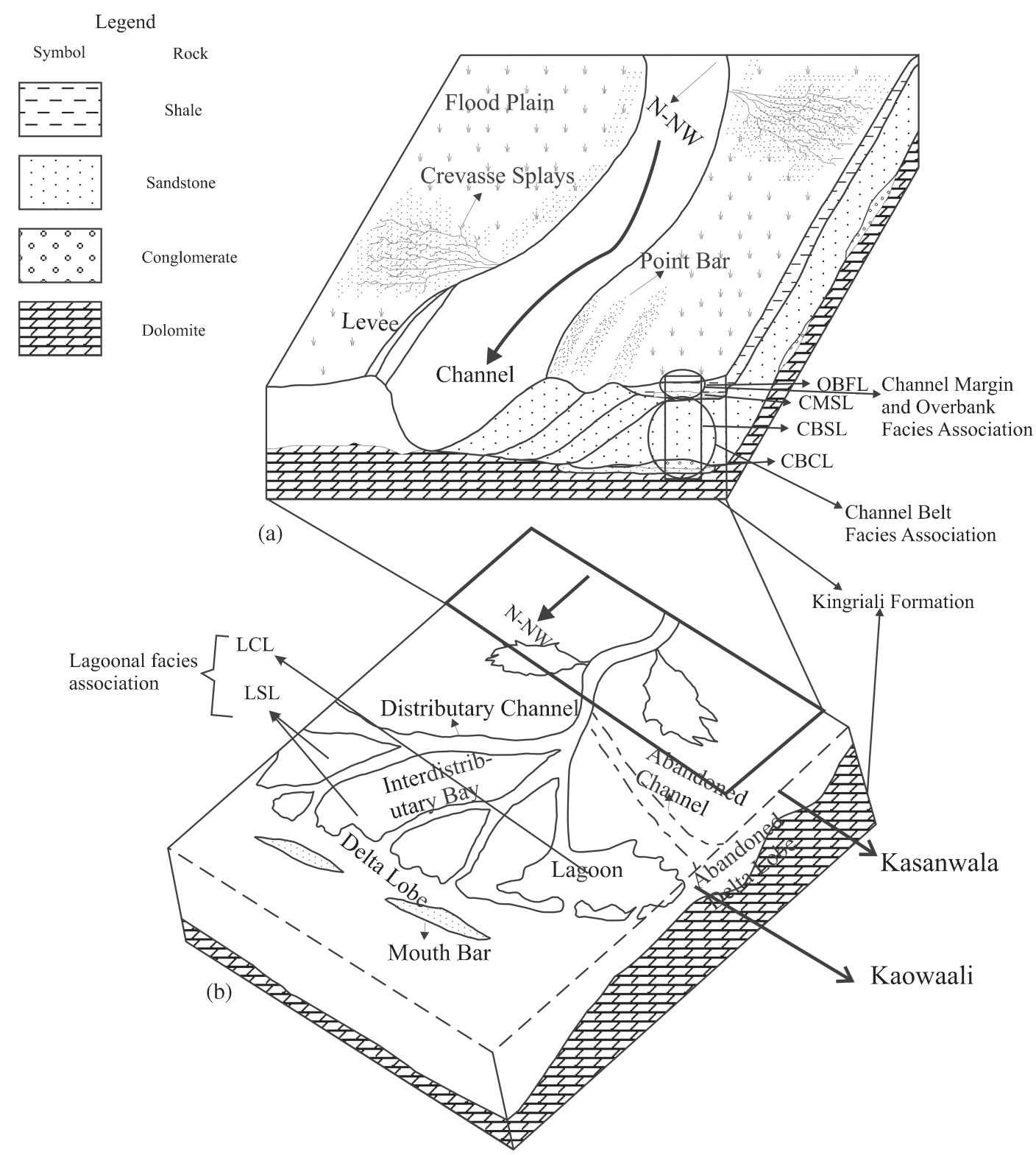

Figure 9. Palaeo-depositional schematic model for the Datta Formation. (a) Elaborated Channel Belt Facies Association consisting of Channel Belt Conglomerate Lithofcaies (CBCL) and Channel Belt Sandstone Lithofacies (CBSL), Channel Margin and Overbank Facies Association (CMOFA) consisting of Channel Margin Sandstone Lithofacies (CMSL) and Overbank/Flood Plain Lithofacies (OBFL). (b) Composite model showing location of the two study sections and distribution of various subenvironments. Lagoonal Facies Association consisting of Lagoonal Shale Lithofacies (LSL) and Lagoonal Carbonate Lithofacies (LCL) are also marked.

adjoining India. However, robust biostratigraphic control is needed to establish this correlation and to establish the palaeogeography for this unit.

\section{Conclusions}

In the western Salt Range (Kaowaali and Kasanwala sections), the Datta Formation is represented by a thick siliciclastic unit having minor carbonates. The dominant lithologies include sandstone, shale/mud, dolomite (both pure and impure), siltstone and clast-supported conglomerate. Prior to this work, no sedimentological studies have been conducted on the Datta Formation of this part of Salt Range.

The lower contact of the formation is disconformable with the Triassic Kingriali Formation and is marked by a residual laterite in both the sections. The basal conglomerate bed has angular fragments derived from the underlying Kingriali Formation. The Channel Belt Conglomerate (CBCL) is composed of pebble to granule and fine-grained particles and compositionally quartz rich oligomicitic conglomerates. The Channel Belt Sandstones (CBSL) are medium to thick bedded, 
fine- to coarse- and very coarse-grained and are quartz arenites. The carbonates include both pure and impure thin- to medium-bedded dolomite. The siltstone and shale/mud show laminations.

The rocks show colour variation from light grey, yellowish grey, to dark grey and even black. Sedimentary structures like cross- and graded-beddings, ripple marks, mudcracks and bioturbation feature are common. Apart form plant remains, no fossils were recognized. Planar and wavy bedding are the most common bedding types.

The Datta Formation is most probably deposited in fluvial-deltaic environments. Grading with good sorting and packing together with cross-bedding indicate that the lower half of the studied sections form part of an incised valley fill and prominent channel belt setting. A point bar succession is interpreted in the meander channel belt setting and consists of the channel belt facies association overlain by channel margin and overbank/flood plain facies association. Mixed lithologies of the lagoonal facies association in the upper half of the studied sections most likely represent lagoonal/lake-deltaic environment (delta plain-delta front). Apart from the channel belt conglomerate lithofacies, the other lithofacies are repeated at several intervals showing the repetition of the depositional cycles in the area.

Two main regression-transgression cycles are interpreted in the formation, of which the lower cycle indicates a more prominent relative sealevel regression and transgression following the Pre-Jurassic type-1 sequence boundary. Prominent LST, TST, and HST are recognized in this cycle. The overlying cycle is similar to the earlier cycle and tentative LST, TST, and HST are recognized. However, more influence of fluvial lateral and vertical migration and delta lobe switching associated with relative sea-level fluctuations is indicated during this time.

The presence of washed, clean silica sand, fire clay horizons, laterites, and numerous palaeosols indicate warm-humid near tropical palaeoclimate during the time of deposition of the Datta Formation.

\section{Acknowledgements}

This study benefited from the Quaid-i-Azam University 'University Research Fund' provided to Mr Shahid Iqbal. NCE in Geology is thanked for providing field support. Authors also thank Dr Muhammad Mujtaba (HDIP), Dr Muhammad Hanif (NCEG) and Prof. Michael Wagreich, Department of Geodynamics and Sedimentology (University of Vienna), for their guidance in this work.

\section{References}

Abbasi A I, Haneef M, Obaid S, Daud F and Quraishi A W 2012 I. A Mesozoic deltaic system along the western margin of the Indian Plate: Lithofacies and depositional setting of Datta Formation, north Pakistan; Arab. J. Geosci. 5 471-480.

Arndorff L 1993 Lateral relations of deltaic paleosols from the lower Jurassic Rønne Formation on the Island of Bornholm, Denmark; Palaeogeogr. Palaeoclimatol. Palaeoecol. 100 235-250.

Arias C 2007 Pliensbachian-Toarcian ostracod biogeography in NW Europe: Evidence for watermass structure evolution; Palaeogeogr. Palaeoclimatol. Palaeoecol. 251 $398-421$.

Ashraf M, Ahmad M and Faruqi F A 1976 Jurassic bauxite and kaolinite deposits of Chhoi area Kala Chitta Range, Punjab, Pakistan; Geol. Bull. Punjab Univ. 41 41-54.

Atkinson C D 1986 Tectonic controls on alluvial sedimentation as resolved by an ancient catena in the Capella Formation (Eocene) of northern Spain; In: Paleosols: Their Reconstruction and Interpretation (ed.) Wright V P, Princeton Univ. Press, Princeton, NJ, pp. 139-179.

Baker D M, Lillie R J, Yeats R S, Johnson G D, Yousuf M and Zamin A S H 1988 Development of the Himalayan frontal thrust zone, Salt Range, Pakistan; Geology 16 $3-7$.

Boggs S Jr 2009 Petrology of Sedimentary Rocks; 2nd edn, Cambridge University Press, pp. 166-193.

Boggs S Jr 2006 Principles of Sedimentology and Stratigraphy; 4th edn; Prentice Hall, Upper Saddle River, NJ.

Blatt H 1982 Sedimentary Petrology; Freeman and Company, New York, pp. 105-241.

Cadle A B and Cairncross B 1993 A sandy, bed-load dominated fluvial system deposited by lateral-accretion: Permian Karoo Sequence, South Africa; Sedim. Geol. 85(1) $435-455$.

Catuneanu O 2006 Principles of Sequence Stratigraphy; Elsevier, pp. 21-24.

Chandler M A 1994 Depiction of modern and Pangean deserts: Evaluation of GCM hydrological diagnostics for paleoclimate studies; In: Pangaea: Paleoclimate, tectonics, and sedimentation during accretion, zenith, and breakup of a supercontinent (ed.) Klein G D, Boulder, CO; Geol. Soc. Am. Spec. Paper 288 117-138.

Chandler M A, Rind D and Ruedy R 1992 Pangaean climate during the Early Jurassic: GCM simulations and the sedimentary record of paleoclimate; Geol. Soc. Am. Bull. 104 $543-559$.

Chaudhry M N, Chuhan F A and Ghazanfar M 1994 Microfacies, diagenesis, environment of deposition and burial history of Datta Formation from Bara Oter, Dist. Abbottabad; Kash. J. Geol. 11 43-59.

Chaudhry M N, Manzoor A and Ghazanfar M 1994 Sedimentology of Datta Formation at Kalapani, Abbottabad, northwest Himalayas; Pakistan. Geol. Bull. Punjab Univ. 89 11-20.

Damborenea E S 2002 Jurassic evolution of Southern Hemisphere marine palaeobiogeographic units based on benthonic bivalves; Geobios Mémoire Spécial $\mathbf{n}^{\circ} \mathbf{2 4}$ 51-71.

Dera G, Pellenard P, Neige P, Deconinck J F, Pucéat E and Dommergues J F 2009 Distribution of clay minerals in Early Jurassic Peritethyan seas: Palaeoclimatic significance inferred from multiproxy comparisons; Palaeogeogr. Palaeoclimatol. Palaeoecol. 271 39-51.

Dunham R J 1962 Classification of carbonate rocks according to depositional texture; In: Classification of carbonate rocks (ed.) Ham W E, Am. Assoc. Petrol. Geol. Memoir 1 108-121. 
Emery D and Myers K 1996 Sequence Stratigraphy; Blackwell Sci. Publ. 11-45 111-178.

Fatmi A N 1974 Lithostratigraphic units of the KohatPotwar Province, Indus Basin, Pakistan; Geol. Surv. Pakistan Memoir 10 6-65.

Fatmi A N 1977 Mesozoic; In: Stratigraphy of Pakistan (ed.) Shah S M I, pp. 29-44.

Fatmi A N, Anwar M, Hussain I, Saeed G and Latif A 1990 Stratigraphy of the Shinawari and Datta formations from the Shinawari area (western Samana Range), Kohat Dist; Geol. Bull. Punjab Univ. 84 47-55.

Fawcett P J, Barron E J, Robison V D and Katz B J 1994 The climatic evolution of India and Australia from the Late Permian to mid-Jurassic: A comparison of climate model results with the geological record; In: Pangaea: Paleoclimate, tectonics, and sedimentation during accretion, zenith, and breakup of a supercontinent (ed.) Klein G D, Boulder, CO Geol. Soc. Am. Spec. Pap. 288 139-157.

Folk R L 1974 Petrology of Sedimentary Rocks; Hemphill Publishing Co., Austin, TX 28.

Freedman M G and Sanders E J 1978 Principles of Sedimentology; John Willy and Sons, New York, Chichester, Brisbane, Toronto, pp. 25-54, 100-130, 190-260.

Ferguson I R and Werritty A 1983 Bar development and channel changes in gravelly River Feshie, Scotland; Spec. Publ. Int. Assoc. Sedim. 6 181-193.

Gaetani M and Garzanti E 1991 Multicyclic history of the northern India continental margin (northwestern Himalaya); Am. Assoc. Petrol. Geol. Bull. 75 1427-1446.

Gee E R 1980 Pakistan geological Salt Range series: Directorate of overseas surveys, United Kingdom, for Govt. of Pakistan and Geol. Survey Pakistan, 6 sheets, scale 1:50,000.

Gee E R 1989 Overview of the geology and structure of the Salt Range, with observations on related areas of north Pakistan; In: Tectonics of the western Himalayas (eds) Malinconi Co L L and Lillie R J, Geol. Soc. Am. Spec. Publ. 232 95-112.

Gowland S and Riding J B 1991 Stratigraphy, sedimentology and paleontology of the Scarborough Formation (Middle Jurassic) at Hundale Point, North Yorkshire; Proc. Yorkshire Geol. Soc. 48 375-392.

Graff-Petersen P and Bondam J 1963 Hasle Klinkerfabrik Clay Pit; Int. Clay Conf. Field Trip C, pp. 1-14.

Hallam A 1981 A revised sea-level curve for the early Jurassic; J. Geol. Soc. London 138 735-743.

Hallam A 1984 Continental humid and arid zones during the Jurassic and Cretaceous; Palaeogeogr. Palaeoclimatol. Palaeoecol. 47 195-223.

Hallam A 1997 Estimates of the amount and rate of sea-level changes across the Rhaetian-Hettangian and Pliensbachian-Toarcian boundaries (latest Triassic to early Jurassic); J. Geol. Soc. London 154 773-779.

Hallam A 2001 A review of the broad pattern of Jurassic sealevel changes and their possible causes in the light of current knowledge; Palaeogeogr. Palaeoclimatol. Palaeoecol. 167 23-37.

Haq B U, Hardenbol J and Vail P R 1987 Chronology of fluctuating sea levels since the Triassic (250 million years ago to present); Science 235 1156-1167.

Ingram R L 1954 Terminology for the thickness of stratification and parting units in sedimentary rocks; Geol. Soc. Am. Bull. 65937.

Iqbal S, Jan U I and Hanif M 2014 The Mianwali and Tredian formations: An example of the Triassic progradational deltaic system in the low-latitude western Salt Range, Pakistan; Arab J. Sci. Engg. 5489-5507, doi: 10.1007/s13369-013-0836-2.
Iqbal S, Jan I U, Akhter G, Wagreich M and Hanif M 2014 Triassic-Jurassic boundary: Evidences from the Tethyan Salt Range, Pakistan and correlation with Europe; J. Himalayan Earth Sci. (Abstract volume; Earth Sciences Pakistan, 2014), pp. 36-37.

Kadri I B 1995 Petroleum Geology of Pakistan; Pakistan Petroleum Limited, Graphic Publ. Karachi, pp. 40-45, 84-92.

Kazmi A H and Jan M Q 1997 Geology and Tectonics of Pakistan; Graphic Publ. Karachi, pp. 25-77, 122-223.

Kazmi A H and Abbas S G 2001 Metallogeny and Mineral Deposits of Pakistan; Graphic Publ. Karachi, pp. 207-215.

Lunt I A, Smith G H S, Best J L, Ashworth P J, Lane S N and Simpson C J 2013 Deposits of the sandy braided South Saskatchewan River: Implications for the use of modern analogs in reconstructing channel dimensions in reservoir characterization; AAPG Bull. 97(4) 553-576.

McKee E D and Weir G W 1953 Terminology for stratification and cross-stratification in sedimentary rocks; Geol. Soc. Am. Bull. 64383.

Marzo M, Nijman W and Puigdefabregas C 1988 Architecture of the Castissent fluvial sheet sandstones, Eocene, South Pyrenees, Spain; Sedimentology 35 881-913.

Massari F 1983 Tabular cross bedding in Messinian fluvial channel conglomerates, South Alps, Italy; Int. Assoc. Sedim. Spec. Publ. 6 287-300.

Miall D A 1985 Archetectural-element analysis: A method of facies analysis applied to fluvial deposits; Earth Syst. Rev. 22(4) 261-308.

Moore G T, Hayashida D N, Ross C A and Jacobson S R 1992 Paleoclimate of the Kimmeridgian/Tithonian (Late Jurassic) world. I. Results using a general circulation model; Palaeogeogr. Palaeoclimatol. Palaeoecol. 93 113150.

Mount J F 1984 Mixing of siliciclastic and carbonate sediments in shallow shelf environments; Geology 12(7) 432-435.

Mujtaba M and Memon A M 1990 Diagenesis and pore space development of Datta Sandstones in Salt Range and Surghar Range, Pakistan; J. Hydrol. Res. 2 57-66.

Mukhopadhyay G, Mukhopadhyay S K, Roychowdhury M and Parui P K 2010 Stratigraphic correlation between different Gondwana Basins of India; J. Geol. Soc. India 76 251-266.

Murris R J 1980 Middle East stratigraphic evolution and oil habitat; Am. Assoc. Petrol. Geol. Bull. 64 597-618.

Nichols G 2000 Sedimentology and Stratigraphy; Blackwell Science, pp. $75-145$.

Obaid S, Qureshi W A and Abbasi I A 2005 Lithofacies, sand-bodies geometry and depositional setting of the Datta Formation in Surghar Range, North Pakistan; SPE/PAPG Tech. Conf. Islamabad, pp. 113-126.

Parrish J T, Ziegler A M and Scotese C R 1982 Rainfall patterns and the distribution of coals and evaporites in the Mesozoic and Cenozoic; Palaeogeogr. Palaeoclimatol. Palaeoecol. 40 67-101.

Pettijohn J F 1974 Sedimentary Rocks; Harper and Row Publ. New York, Evanston, San Francisco, and London, pp. 195-246, 316-380.

Pettijohn F J 1975 Sedimentary Rocks; 3rd edn, Harper and Row, New York, NY, pp. 157-166.

Pettijohn F J, Potter P E and Siever R 1973 Sand and sandstone, Springer-Verlag, Berlin, 617p.

Posamentier H W and Vail P R 1988 Eustatic controls on clastic deposition. I. Sequences and systems tract models; In: Sea-level changes: An integrated approach (eds) Waligus C K, Hastings B S, Kendall C G St. C, Posamentier H W, Ross C A and Van Wagoner J C, Soc. Econ. Paleontol. Miner. Tulsa. USA Spec. Publ. 42 109-124. 
Posamentier H W, Jervey M T and Vail P R 1988 Eustatic controls on clastic deposition. II. Computational framework; In: Sea-level changes: An integrated approach (eds) Waligus C K, Hastings B S, Kendall C G St. C, Posamentier H W, Ross C A and Van Wagoner J C, Soc. Econ. Paleontol. Miner. Tulsa. USA Spec. Publ. 42 125-154.

Price I 1977 Deposition and derivation of clastic carbonates on a Mesozoic continental margin, Orthis, Greece; Sedimentology 24 529-546.

Rafique M, Ashraf M, Din A and Faruqi F A 1976 Evaluation of glass sand deposits of Pezu, Bannu Dist. N.W.F.P; Geol. Bull. Punjab Univ. 45 87-92.

Rees P M, Gibbs M T, Ziegler A M, Kutzbach J E and Behling P J 1999 Permian climates: Evaluating model predictions using global paleobotanical data; Geology $\mathbf{2 7}$ 891-894.

Rees P M, Ziegler A M and Valdes P J 2000 Jurassic phytogeography and climates: New data and model comparisons; In: Warm climates in Earth history (eds) Huber B T, Macleod K G and Wing S L, Cambridge University Press, pp. 297-318.

Rees P M, Ziegler A M, Gibbs M T, Kutzbach J E, Behling P J and Rowley D B 2002 Permian phytogeographic patterns and climate data/model comparisons; J. Geol. 110 $1-31$.

Reineck E H and Singh B I 1975 Depositional Sedimentary Environments; Springer-Verlag, Berlin: Heidelberg, New York, pp. 21-32, 41-44, 81-147, 225-279.

Remin Z, Krogulec T, Drela T and Surowski M 2014 The recognition of hailstone impressions in clay-rich sediment: Experimental results and relation to the neoproterozoic case; J. Sedim. Res. 84 543-551.

Reynolds A D 1994 Sequence stratigraphy and the dimensions of paralic sandstone bodies; In: High resolution sequence stratigraphy: Innovations and applications (ed.) Johnson S D, Univ. Liverpool, pp. 69-72.

Richards M T 1994 Transgression of an estuarine channeltidal flat complex: The Lower Trias of Barles, Alpes de Haute Provence; Sedimentology 42 1-27.

Ryer T A 1981 Deltaic controls on Ferron Sandstone Member of Mancos Shale: Predictive model for Cretaceous coal-bearing strata of western interior; Am. Assoc. Petrol. Geol. Bull. 65 2323-2340.

Ryseth A 1989 Correlation of depositional pattern in the Ness Formation, Oseberg area; In: Correlation in Hydrocarbons Exploration (ed.) Collinson J D, Graham \& Trotman, London, pp. 313-326.

Scotese C R 1994 Early and Middle Jurassic maps; In: Pangaea: Paleoclimate, tectonics, and sedimentation during accretion, zenith, and breakup of a supercontinent (ed.) Klein G H, Geol. Soc. Am. Spec. Pap. 288 57-73.

Shah I M S 1977 Stratigraphy of Pakistan; Geol. Surv. Pakistan Quetta Memoir 12 3-4, 6-8, 23-29, 40-43.

Shah S M I 2009 Stratigraphy of Pakistan; Govt. Pak Ministry of Petrol \& Nat. Resour. Geol. Sur. Pakistan, pp. 245-273.
Shanley K W, McCabe P J and Hettinger R D 1993 Tidal influence in Cretaceous fluvial strata from Utah, USA: A key to sequence stratigraphic interpretation; Sedimentology 39 905-930.

Smith G H S, Ashworth P J, Best J L, Lunt I A, Orfeo O and Parsons D R 2009 The sedimentology and alluvial architecture of a large braid bar, Río Paraná, Argentina; J. Sedim. Res. 79(8) 629-642.

Smith G H S, Best J L, Bristow C S and G E Petts (eds) 2006 Braided rivers: Process, deposits, ecology and management; Int. Assoc. Sedim. Spec. Publ. 36.

Tornqvist T E 1993 Holocene alteration of meandering and anastomosing fluvial systems in the Rhine-Meuse delta (central Netherlands) controlled by sea level rise.

Tucker E M 1986 Sedimentary Petrology: An Introduction; Blackwell Sci. Publ., pp. 10-63, 96-158.

Tucker E M 1988 Techniques in Sedimentology; Blackwell Sci. Publ., pp. 91-223.

Tucker E M 1992 Sedimentary petrology: An introduction to the origin of sedimentary rocks; Blackwell Sci. Publ., pp. 10-65, 125-154.

Van Wagoner J C, Mithcum R M Jr, Campion K M and Rahmanian V D 1990 Siliciclastic sequence stratigraphy in well logs, cores and outcrop: Concepts for high resolution correlation of time and facies; Am. Assoc. Petrol. Geols. Methods in Exploration Series, Tulsa. 755.

Valdes P J 1994 Atmospheric general circulation models of the Jurassic; In: Palaeoclimates and their modeling with special reference to the Mesozoic Era (eds) Allen J R L, Hoskins B J, Sellwood B W, Spicer R A and Valdes P J (London: Chapman and Hall), pp. 109118.

Valdes P J and Sellwood B W 1992 A palaeoclimate model of the Kimmeridgian; Palaeogeogr. Palaeoclimatol. Palaeoecol. 95 47-72.

Verma D, Jadhav G N, Biswal T K, Jena S K and Sharma N 2012 Characterization of hydrocarbon-bearing fluid inclusion in sandstones of Jaisalmer basin, Rajasthan: A preliminary approach; J. Geol. Soc. India 80 505-514.

Westcott W A 1993 Geomorphic thresholds and complex response of fluvial systems - some implications of sequence stratigraphy; Am. Assoc. Petrol. Geol. Bull. (abstract) 77 208-218.

Willis B J 1989 Palaeochannel reconstructions from point bar deposits: A three dimensional perspective; Sedimentology 36(5) 757-766.

Wood L J 1990 Effects of basin type on coastal plainshelf slope systems during base level fluctuations: An experimental approach; Am. Assoc. Petrol. Geol. Bull. (abstract) $\mathbf{7 5} 969$.

Wood L J, Ethridge F G and Schumm S A 1991 Influence of subaqueous shelf angle on coastal plain-shelf slope deposits resulting from a rise or fall in base level; $A m$. Assoc. Petrol. Geol. Bull. (abstract) 75969.

Ziegler P A 1982 Geological atlas of western and central Europe, 130 (Hague: Elsevier for Shell Internationale Petroleum Maatschappij). 